Thorns in the Flesh 
DIVINATIONS: REREADING LATE ANCIENT RELIGION

Series Editors: Daniel Boyarin, Virginia Burrus, Derek Krueger

A complete list of books in the series is available from the publisher. 


\section{Thorns in the Flesh}

Illness and Sanctity in Late Ancient Christianity

Andrew Crislip

\section{$\overline{\text { PENN }}$}

UNIVERSITY OF PENNSYLVANIA PRESS

PHILADELPHIA 
Copyright (C) 20I3 University of Pennsylvania Press

All rights reserved. Except for brief quotations used for purposes of review or scholarly citation, none of this book may be reproduced in any form by any means without written permission from the publisher.

Published by

University of Pennsylvania Press

Philadelphia, Pennsylvania I9I04-4II2

www.upenn.edu/pennpress

Printed in the United States of America on acid-free paper

IO 99876654332 I

A Cataloging-in-Publication record is available from the Library of Congress

ISBN 978-0-8I22-4445-8 
For Grace and Renna 
This page intentionally left blank 